\title{
Az EU és az EFTA: a két gazdasági integráció (tagjai) közötti együttmüködés támogatási rendszere
}

\author{
Európai Gazdasági Térség Finanszírozási Mechanizmus \\ - Norvég Finanszírozási Mechanizmus - Svájci Hozzájárulás \\ - kohéziós támogatás - regionális politika - belső piac
}

Az Európai Unió, illetve a tagállamai, valamint az Európai Szabad Kereskedelmi Társulás (European Free Trade Association, továbbiakban EFTA) országai közötti gazdasági kapcsolatok sajátos elemeit képezik az integrációs pénzügyi jognak, melyek hatással vannak a magyar költségvetési jogra is. A tanulmány keretében többek között arra keressük a választ, hogy mi lehet az oka annak, hogy egyes Európai Unión kívüli országok viszonylag jelentős összegekkel támogatnak egyes uniós tagállamokat, ehhez miért és hogyan kötődik az EU, e támogatások milyen jellemzőkkel bírnak, és Magyarország hogyan kapcsolódik ezen kormányzati szintek közötti pénzügyi kapcsolatok rendszerébe.

\section{Az EU-EFTA együttmüködés keretei, elméleti alapok}

Az 1960. január 4-én megkötött stockholmi egyezményen alapuló szabad kereskedelmi övezet, ${ }^{1}$ az Európai Szabad Kereskedelmi Társulás (European Free Trade Association, továbbiakban EFTA) tagjainak köre az utóbbi évtizedekben jelentősen változott. Az alapító tagok (Ausztria, Dánia, Nagy-Britannia, Norvégia, Portugália, Svájc és Svédország) a „Hetek” integrációjaként váltak ismertté, szemben a Római Szerződéseket aláíró „Hatokkal”. A szorosabb együttműködésen alapuló Európai Közösségek keretében elért eredmények és az európai országok közötti gazdasági interdependencia miatt amellett, hogy egyes EFTA-tagok csatlakoztak a Közössé-

* Dr. Csűrös Gabriella egyetemi adjunktus, Debreceni Egyetem Állam- és Jogtudományi Kar Pénzügyi Jog és Közmenedzsment Tanszék, csuros.gabriella@law.unideb.hu. A kutatás az Európai Unió és Magyarország támogatásával, az Európai Szociális Alap társfinanszírozásával a TÁMOP 4.2.4.A/2-11-1-2012-0001 azonosító számú „Nemzeti Kiválóság Program - Hazai hallgatói, illetve kutatói személyi támogatást biztosító rendszer kidolgozása és működtetése konvergencia program" című kiemelt projekt keretei között valósult meg. A tanulmány lezárásának dátuma: 2013. 08. 01.

1 Az EFTA keretében a szabad kereskedelem nem teljes, csak az ipari termékekre vonatkozik. 
gekhez, illetve az Unióhoz, ${ }^{2}$ az intézményesített gazdasági együttmüködés pozitív hozadékainak elismeréseként új nyugat-európai országok váltak az EFTA tagjaivá. ${ }^{3}$ Ezeken túl sajátos megoldásokat eredményezett a két gazdasági integráció, illetve az azok tagállamai közötti együttműködés. 1972-ben az akkori EFTA-tagországok ${ }^{4}$ szabad kereskedelmi megállapodást kötöttek a kibővült Közösségekkel, valamint annak tagállamaival, bár csak 1977 júliusára valósult meg az EFTA-országok és a Közösségek között az ipari szabad kereskedelmi övezet. 1994-töl pedig tovább mélyült az EU és az EFTA, illetve azok tagjai közötti kooperáció. Milyen sajátos együttmüködési formákat alakítottak ki?

Az EU kilencvenes évekbeli bővülése jól illusztrálja azt, hogy a fejlett nyugati országok közül némelyik a szorosabb - többek között a fokozódó monetáris politikai - együttmüködést nem volt hajlandó elfogadni. Az uniós tagságot továbbra is elutasító EFTA-államok és az EU azonban egy közös érdekeltségi rendszert dolgoztak ki - mindkét irányban többletjogokkal és -kötelezettségekkel. Ennek adta kereteit az Európai Gazdasági Térség és a Svájccal való szorosabb együttmüködés.

Az 1994. január 1-jén hatályba lépő, az Európai Gazdasági Térségről szóló megállapodás ${ }^{5}$ alapján egyrészröl az Európai Közösségek és annak 12 akkori tagállama, másrészről Svájc kivételével az akkori EFTA-tagállamok ${ }^{6}$ a négy szabadságjogot megvalósító közös piacot hoztak létre. Bár az EGT keretében megvalósított együttmüködés nem terjed ki több uniós politikára, ${ }^{7}$ az egységes belső piac közös megvalósításával szorosabb gazdasági és politikai együttmüködést eredményez, mint az

2 Dánia és az Egyesült Királyság 1973-ban nyertek felvételt a Közösségekbe, Ausztria, Finnország és Svédország pedig 1995-ben csatlakozott az Európai Unióhoz. Ezzel egyidejűleg Norvégiában másodjára is elutasították az uniós csatlakozást (elöször 1973-ban), így Norvégia továbbra is EFTA-tag.

3 Izland 1970-ben csatlakozott az EFTA-hoz, Liechtenstein pedig 1991-ben. Finnország 1961 óta társult tagja, majd 1986-1995 között teljes jogú tagja volt az EFTA-nak. http://www.efta.int/about-efta/the-efta-states. aspx (2013. 07. 15.)

4 Az 1977-re megvalósuló ipari szabad kereskedelmi övezetnek az Egyesült Királyság és Dánia már nem mint EFTA-, hanem mint EK-tag voltak részesei.

5 Megállapodás az Európai Gazdasági Térségröl. A megállapodást hazánkban a 2006. évi CXXVI. törvény hirdette ki.

6 Az EFTA akkori tagállamai közül a megállapodást aláírók az alábbiak voltak: az Osztrák Köztársaság, a Finn Köztársaság, az Izlandi Köztársaság, a Liechtensteini Hercegség, a Norvég Királyság és a Svéd Királyság. Az EFTA-államok közül tehát Svájc nem csatlakozott az EGT-hez, miután 1992. december 6-án a svájci lakosok népszavazáson elutasították az EGT-ben való részvételt. Emellett 1995-ben Ausztria, Finnország és Svédország csatlakozott az Európai Unióhoz, ami miatt a három ország EFTA-tagsága megszűnt. Így jelenleg az EFTA keretében Izland, Liechtenstein és Norvégia azok, akik az Európai Unióval való szorosabb gazdasági együttmüködésben részt vesznek, Svájc pedig egyedüli EFTA-tagállam, amely továbbra is kimarad az EGT keretében megvalósuló kooperációból.

7 Az együttműködés nem terjed ki például a közös agrár- és halászati politikára, a vámunióra, a közös kereskedelempolitikára, a közös kül- és biztonságpolitikára, a bel- és igazságügyi együttmüködésre, a közvetett és közvetlen adókra, a gazdasági és monetáris unióra. Ezeken a területeken az együttműködés sajátossága tovább árnyalható, hiszen az EGT-megállapodás tartalmaz többek között a mezőgazdasági és halászati termékek kereskedelmére vonatkozó különböző rendelkezéseket, illetve a bel- és igazságügyi együttműködés kapcsán Izland, Liechtenstein és Norvégia is részese a Schengeni Egyezménynek. Forrás: Subcommittee on Legal and Institutional Questions: How EU acts become EEA acts and the need for adaptions. 23 May 2013. http://www.efta.int/eea.aspx (2013. 07. 20.). 
EGT-n kívüli Svájc és az EU közötti, szabad kereskedelmi övezeten alapuló bilaterális kapcsolatok rendszere.

Az Európai Gazdasági Térség több szempontból is sajátos gazdasági integrációs forma. Egyrészt (Svájcot kivéve) két európai gazdasági integráció, illetve tagjai együttmüködésének ad keretet. Érdekesség, hogy az EFTA csupán szabad kereskedelmi övezet, a három EFTA-tag az Unióval viszont a szabad kereskedelmi övezetnél szorosabb együttmüködést, belső piacot alakított ki. Az együttmüködés alanyai mellett másrészt sajátos az együttmüködés formája is, hiszen a gazdasági integrációk lépcsőfokait figyelembe véve két nem egymást követő szakasz sajátos ötvözetét adja: az Európai Gazdasági Térségben a szabad kereskedelmi övezet és a közös piac egyaránt megvalósul (még ha korlátozottan is), azonban a tagállamok nem léptek vámunióra. Az EGT keretében megvalósuló szorosabb együttmüködés jogi és intézmény ${ }^{8}$ háttere mellett a költségvetési kapcsolatok is egyedi vonásokkal bírnak. Az EGT-megállapodás 1994. évi hatálybalépése óta ugyanis az EGT-hez tartozó EFTAállamok többéves pénzügyi kereteket bocsátanak rendelkezésre az EGT-n belüli gazdasági és szociális különbségek csökkentése céljából. Ezen Unión kívüli támogatások kizárólagos jogosultjai pedig alapvetően az uniós regionális politika keretében működő Kohéziós Alap által támogatott, úgynevezett kohéziós országok.

Az Európai Unió az EGT-államokon kívül Svájccal folytatja a legintenzívebb gazdasági, kereskedelmi kapcsolatokat különböző szektorokhoz kapcsolódó bilaterális megállapodások alapján. ${ }^{9}$ Így Svájc, bár nem tagja az Európai Gazdasági Térségnek, jelentős mértékben részesül a belső piac által biztosított előnyökből, részt vesz számos uniós programban. Svájc abból a célból, hogy az EU-hoz újonnan (2004-töl) csatlakozó európai államok gazdasági és társadalmi egyenlőtlenségeinek csökkentéséhez hozzájáruljon, 2006-ban döntött a Svájci Hozzájárulás létrehozásáról, ${ }^{10}$ amelynek keretében szintén az Európai Unió kohéziós országainak nyújt vissza nem térítendő támogatásokat. Mi lehet ezen, kohéziós célú támogatások oka?

8 Az EGT keretében felállított intézményrendszer két pillérből, az uniós és az EFTA-pillérből áll. Emellett az EGT közös intézményrendszert is müködtet, melynek keretében az uniós acquis átvételével kapcsolatos iránymutatásokat az évente legalább kétszer ülésező EGT Tanács, míg az iránymutatások alapján az átvételre vonatkozó döntéseket az évente 6-8 alkalommal ülésező Vegyes Bizottság hozza meg. Tehát azon belső piaci szabályokat, amelyek nem válnak automatikusan az EGT Európai Unión kívüli tagjainak joganyagává, azokat a Vegyes Bizottság fogadja el, amelyekben (a 2894/94/EK rendelet 1. cikke alapján) technikai kérdésekben a Bizottság, érdemi döntések esetén pedig a Tanács dönt az EU részéröl. A Lisszaboni Szerződés hatálybalépése óta pedig a Vegyes Bizottságban - az EFTA-tagok képviselői mellett - az Európai Külügyi Szolgálat látja el a Bizottság helyett az Unió képviseletét. Az EFTA-államok között létrejött megállapodás értelmében a Felügyeleti Hatóság és az EFTA Bíróság biztosítja Izland, Liechtenstein és Norvégia esetében az EGT Megállapodás keretében vállalt kötelezettségek betartását (az uniós tagállamok vonatkozásában az Európai Bizottsághoz és az Európai Bírósághoz hasonló feladat- és hatáskörökkel). Forrás: Agreement between the EFTA States on the Establishment of a Surveillance Authority and a Court of Justice. (OJ L 344., 31.1.1994., p. pp. 1-7.), a Tanács 2894/94/EK rendelete (OJ L 305., 30.11.1994., pp. 6-8.), http://www.efta.int/, http://www.eftasurv.int (2013. 07. 15.).

9 http://eeas.europa.eu/switzerland/index_en.htm (2013. 07. 16.).

10 Azzal egyidejüleg, hogy Svájc és az EU megállapodott a Svájci Hozzájárulás felállitásáról, újabb bilaterális megállapodások megkötésére került sor Svájc és az Unió között. Forrás: European Commission IP/06/234, 27/02/2006. http://europa.eu/rapid/press-release_IP-06-234_en.htm?locale=en (2013. 07. 13.). 
Teoretikus szinten az EFTA-országok kohéziós célú támogatásaira a magyarázatot leginkább a közös piachoz kapcsolódó közgazdasági elméletek adják meg. ${ }^{11}$ A napjainkban uralkodó nézetek szerint a tényezők (köztük a tőke és a munkaerő) szabad áramlása az integrációban részt vevő tagállamok közötti diszparitás, az egyenlőtlenségek növekedéséhez vezet. Kiegészítésként ez a piaci elégtelenségek, az ún. piaci kudarcok rendszerén belül különösen a nem teljes (vagy tökéletlen) piacokhoz és a negatív externáliákhoz kapcsolható jelenség. ${ }^{12} \mathrm{Az}$ uniós belső piacra vetítve mindezt, a közös piac előtt álló akadályok Unión belüli leépítése negatív gazdasági hatással lehet egyes piaci szereplőkre és földrajzi területekre, tovább növelheti a fejlettségbeli különbségeket. Az Európai Unió mint sajátos kormányzati szint egyik fő célkitűzésének (a négy alapszabadságnak) a biztosítása mellett a közös piachoz kapcsolódó piaci kudarcok kezeléséhez is hozzá kíván járulni - többek között a regionális politika keretében nyújtott támogatásokkal. Az EGT-ben részt vevő EFTAországok tehát ehhez hasonlóan az uniós belső piacból származó előnyök élvezete ellenében a belső piac okozta piaci kudarcok kezeléseként nyújtanak kohéziós célú támogatásokat az Unió fejlődésben legelmaradottabb tagállamai számára.

A tanulmány célja a továbbiakban az EFTA-államok által finanszírozott pénzügyi eszközök összehasonlító bemutatása, elemzése. ${ }^{13}$ Az EGT-ben részt vevő EFTA államok finanszírozási mechanizmusait és a Svájci Hozzájárulást külön-külön, majd egymással és az uniós kohéziós támogatásokkal összehasonlítva vizsgáljuk, figyelemmel hazánk érintettségére.

11 Ezekröl lásd: PalÁnKal Tibor: Az európai integráció gazdaságtana. Aula Kiadó, Budapest, 2004, 92-103; Koczıczky György: Regionális integrációk gazdaságtana. Miskolci Egyetemi Kiadó, Miskolc, 2008, 88-92; Kengyel Ákos: Kohézió és finanszírozás. Akadémiai Kiadó, Budapest, 2008. 65-66. Az elméletek feldolgozását lásd CsüRös Gabriella: Az Európai Unió mint regionális gazdasági integráció egyes pénzügyi jogi aspektusai, PhD-értekezés (2012) 102-110. (Elérhető: http://www.doktori.hu)

12 Ezekröl részletesebben lásd például: NEMEC, Juraj-WRIGHT, Glen: Közösségi pénzügyek: elmélet és gyakorlat a közép-európai átmenetben. Aula Kiadó, Budapest, 2000, 68-75, 78.

13 Az EFTA-országok pénzügyi eszközei mellett további pénzügyi kapcsolatok is jellemzik az EU és az EFTAországok viszonyrendszerét. Norvégia, Izland és Liechtenstein például részt vesz az EU többéves pénzügyi tervének 1a., 3a., 3b., 4. és 5. címsorában szereplő uniós politikák finanszírozásában, egy ún. arányossági tényező alapján meghatározott mértékben, amelyröl az éves uniós költségvetés külön melléklete rendelkezik. Ugyanakkor az EFTA-államok, illetve azok területi egységei jogosultak részt venni az uniós költségvetés által finanszírozott határon átnyúló együttműködési programokban, emellett az Európai Beruházási Bank évente több millió euró összegü fejlesztési hitelt nyújt az EFTA-államokban megvalósuló projektek finanszírozására (2012-ben például 735,3 millió euró összegű hitel állt rendelkezésre az EFTA-országokban megvalósuló nyertes projektek támogatására). Ezek vizsgálata azonban nem képezi a tanulmány tárgyát. Ezekről lásd: http://eur-lex.europa.eu/budget/www/index-hu.htm (2013. 07. 13.), European Investment Bank: Financial Report, 2012. p. 45. 


\section{Az Európai Gazdasági Térség Finanszírozási Mechanizmus és a Norvég Finanszírozási Mechanizmus}

\subsection{A két finanszírozási mechanizmus szabályozásának keretei}

Az Európai Gazdasági Térség keretében létrehozott, jelenleg müködő támogatási rendszer, az Európai Gazdasági Térség Finanszírozási Mechanizmus (továbbiakban EGT FM) és a Norvég Finanszírozási Mechanizmus (továbbiakban Norvég FM) jogszabályi kereteit kormányközi együttműködés keretében született dokumentumok adják. A hivatalos tárgyalások lezárultát követően (amire legutóbb késedelmesen, 2009. december 18-án került sor) a szerződő felek (az EGT FM esetében az EU, Izland, Liechtenstein és Norvégia, a Norvég FM esetében az EU és Norvégia) megállapodást kötnek. ${ }^{14} \mathrm{~A}$ megállapodást (amelyet legutóbb 2010. július 28-án írtak alá) mindegyik szerződő fél a saját eljárási rendje szerint megerősíti vagy jóváhagyja. Az EU Tanácsa határozatot fogad el ennek keretében, ${ }^{15}$ amelynek (a Lisszaboni Szerződés által módosult) jogalapja az EUMSZ 175. cikk harmadik albekezdése, illetve a 207. cikk ${ }^{16}$ és a 218. cikk (6) bekezdés a) pontja. Megállapítható, hogy az EUMSZ 175. cikke harmadik albekezdésének jogalapként való megjelölése már kapcsolatot mutat az EU kohéziós politikájával. A két finanszírozási mechanizmus további jogalapjául szolgáló EUMSZ 218. cikk (6) bekezdés a) pontja értelmében a Tanács a Parlament egyetértését követően hoz határozatot azon megállapodások megkötéséröl, melyek együttmüködési eljárások útján külön intézményi keretet hoznak létre, illetve melyek az EU-ra nézve jelentős költségvetési kihatással járnak.

Ezt követően a Norvég FM esetében Norvégia, az EGT FM esetében az EGT-ben részt vevő EFTA-államok minden egyes kedvezményezettel külön együttműködési megállapodást kötnek, melyben a nemzeti prioritásokra figyelemmel meghatározzák az alapvető szabályokat (így a többéves program keretét, igazgatási és ellenőrzési struktúráit). Hazánk vonatkozásában az EGT FM 2009-2014-es időszakának végrehajtásáról szóló, 2011. október 12-én aláírt együttmüködési megállapodást a 235/2011. (XI. 15.) sz. kormányrendelet hirdette ki, míg a Norvég FM együttmüködési megállapodást a 236/2011. (XI. 15.) sz. kormányrendelet. Az együttmüködési megállapodások megkötését hosszas tárgyalási és elökészítési folyamat kísérte, ${ }^{17}$ így a 2009-2014 közötti támogatási időszak keretében az első pályázati felhívások meghirdetésére hazánkban csak 2013 nyarán került sor. A pályáztatás 2014. április 30-ig tart, viszont a nyertes projektek megvalósításának határideje 2016. április $30 .{ }^{18}$

14 http://www.eeagrants.org/id/1908 (2013. 07. 26.)

15 A Tanács 2010/674/EU határozata (HL L 291., 2010.11.9., 1-3. o.)

16 Az EUMSZ 207. cikk azonban nem a két finanszírozási mechanizmusnak, hanem az ezekkel egyidejüleg készült kiegészítő jegyzőkönyveknek a jogalapja, amelyek Izlandnak és Norvégiának bizonyos halászati termékekre vonatkozóan vámengedményeket biztosítanak 2009-2014 között.

17 A tagállamokban az egyes területekért felelős szervek 2012 folyamán dolgozták ki és nyújtották be a donor országok részére a támogatott területekre vonatkozó részletes programjavaslatokat, melyek donor országok általi értékelését követően került sor a - pályáztatás megkezdését lehetővé tevő - jóváhagyásra.

$18 \mathrm{http}: / / w w w . n o r v e g a l a p . h u / a l t a l a n o s-l e i r a s \# k i k-p a l y a z h a t n a k ~(2013.07 .28$.). 
A két finanszírozási mechanizmus gyakorlati alkalmazására vonatkozóan az EFTAállamok további útmutatásokat is kibocsáthatnak a kedvezményezett államokkal folytatott konzultációt követően, ${ }^{19}$ valamint a kedvezményezett államok is elfogadnak a két mechanizmus végrehajtására vonatkozó szabályokat [Magyarországon az EGT és a Norvég FM 2009-2014-es végrehajtási rendjéről a 326/2012. (XI. 16.) sz. kormányrendelet ${ }^{20}$ rendelkezik].

\subsection{A két finanszírozási mechanizmus keretében nyújtott támogatások}

Az első pénzügyi keretet 1994. 01. 01.-1998. 12. 31. között bocsátották rendelkezésre az akkori EGT-tag EFTA-államok. Az ekkor létrehozott EGT-EFTA Finanszírozási Mechanizmus keretében más kedvezményezett államok, más kiemelt prioritások alapján részesedtek támogatásban, ami nemcsak közvetlen támogatások formájában öltött testet, hanem az Európai Beruházási Bank (European Investment Bank, továbbiakban EBB) által nyújtott kedvezményes kamatozású kölcsönök formájában is. Ez a tény járult hozzá ahhoz, hogy ebben az időszakban a mechanizmus menedzsmentje is sajátosan épüljön fel (amelynek keretében az EBB is érdemi feladatokat látott el). ${ }^{21}$

A kedvezményezett területek többnyire megegyeznek a szintén 1994-től működő uniós Kohéziós Alap akkori kedvezményezett államaival (Írország, Görögország, Portugália, Spanyolország). Különbség, hogy Spanyolország esetében csak 10 régió jogosult támogatásra (ezáltal szűkebb a területi lefedettség), másrészt azonban ÉszakÍrország vonatkozásában Nagy-Britannia is a kedvezményezett országok közé került. A 2. táblázat adatai alapján a leginkább támogatott területek egybeesnek a szintén 1994-től működő közösségi Kohéziós Alap támogatások prioritásaival; a közlekedést ezen belül inkább fejlesztési hitelekkel segítették, a környezetvédelmet (beleértve a városfejlesztést is) pedig vissza nem térítendő támogatásokkal. Az EGT FM keretében a legkisebb összeggel támogatott oktatás és a képzés viszont nem tartozik a Kohéziós Alap prioritásai közé, inkább az akkori közösségi regionális politika Európai Szociális Alapja által támogatott humánerőforrás-fejlesztés céljával állítható párhuzamba.

A 2000. május 22-én elfogadott, az EGT-megállapodás részét képező 31. Jegyzőkönyv kiegészítése ${ }^{22}$ értelmében az EGT-EFTA-államok (Izland, Liechtenstein és Norvégia) egy új pénzügyi keret, a Finanszírozási Eszköz keretében biztosítottak

19 Ilyen az EGT-tagállamok és Norvégia által elfogadott, az EGT és a Norvég Finanszírozási Mechanizmus végrehajtására vonatkozó mindenkori Szabályzat és Eljárásrend, valamint az Útmutatók. (A 2013. július 8-tól hatályos általános pályázati útmutató: General Application Guide for the EEA and Norwegian Financial Mechanism 2009-2014.)

20 326/2012. (XI. 16.) sz. kormányrendelet az EGT Finanszírozási Mechanizmus és a Norvég Finanszírozási Mechanizmus 2009-2014-es időszakának végrehajtási rendjéről.

21 Az EBB volt ugyanis felelős a projektek értékeléséért, monitoringjáért, valamint a pénzügyi, gazdasági és technikai feltételek teljesítése esetén (figyelemmel az EU céljaira, ágazati politikáira és környezetvédelmi szabályozására is) a kifizetésért is.

22 Amendment of Protocol 31, 2000. 
kohéziós célú támogatásokat a korábbi kedvezményezetteknek 1999-2003 között. ${ }^{23}$ A mechanizmus és az EU (ezen belül a kohéziós politika) közötti szoros kapcsolatot támasztja alá, hogy maga az EU döntött arról, hogy a kedvezményezett államok a Finanszírozási Eszköz támogatási keretéből milyen mértékű támogatást kapjanak. ${ }^{24}$ A kedvezményezett államok támogatottságának egymáshoz viszonyított aránya jelentősen nem változott, Spanyolország támogatottsága valamelyest (13,3\%-kal) nőtt, emiatt más országoké csökkent. Ebben az időszakban a Finanszírozási Eszköz keretében már nem nyújtott az EBB kedvezményes kamatozású kölcsönöket, a vissza nem térítendő támogatások összességében pedig egyötödére csökkentek. Az 1994 és 2003 között az EGT-EFTA-tagállamok által rendelkezésre bocsátott keretek eloszlását az alábbi táblázat szemlélteti.

\section{1. táblázat}

Az EGT Finanszírozási Mechanizmusok rendelkezésre álló keretei (1994-2003, EUR)

\begin{tabular}{|l|r|r|r|r|r|r|}
\hline \multirow{2}{*}{$\begin{array}{c}\text { Kedvezmé- } \\
\text { nyezett }\end{array}$} & \multicolumn{3}{|c|}{ EGT-EFTA FM rendelkezésre álló kerete } & \multicolumn{2}{c|}{$\begin{array}{c}\text { Finanszírozási } \\
\text { Eszköz kerete } \\
\text { (1994-1998) }\end{array}$} \\
\cline { 2 - 8 } & Támogatás & EBB-kölcsön & $\begin{array}{c}\text { Összesen } \\
\text { (EUR) }\end{array}$ & $\begin{array}{c}\text { Összesen } \\
\text { (1\%) }\end{array}$ & $\begin{array}{c}\text { Összesen } \\
\text { (EUR) }\end{array}$ & $\begin{array}{c}\text { Összesen } \\
\text { (\%) }\end{array}$ \\
\hline $\begin{array}{l}\text { Spanyolország } \\
\text { (10 régiója) }\end{array}$ & 227000000 & 681000000 & 908000000 & 45,4 & 70181280 & 58,7 \\
\hline Görögország & 121500000 & 364500000 & 486000000 & 24,3 & 22078160 & 18,5 \\
\hline Portugália & 105000000 & 315000000 & 420000000 & 21,0 & 21288800 & 17,8 \\
\hline Írország & 35500000 & 106500000 & 142000000 & 7,1 & 5525520 & 4,6 \\
\hline $\begin{array}{l}\text { Nagy-Britannia } \\
\text { (Észak-Írország) }\end{array}$ & 11000000 & 33000000 & 44000000 & 2,2 & 526240 & 0,4 \\
\hline Összesen & 500000000 & 1500000000 & 2000000000 & 100,0 & 119600000 & 100,0 \\
\hline
\end{tabular}

Forrás: saját szerkesztés ${ }^{25}$

Az 1994-1998, valamint az 1999-2003-as időszak közötti finanszírozási mechanizmusok preferált területei megegyeznek, azonban az azok közötti támogatáselosztás szélsőségesebb értékeket mutat. Az EBB-hitelek elmaradása miatt a közlekedési projektek által elnyert hozzájárulások összege jelentősen csökkent, alapvetően a környezetvédelmi és az ahhoz kapcsolt (pl. kulturális örökségvédelmi) támogatások allokációja volt meghatározó.

23 Mivel a finanszírozó államok nemzeti jogrendjük keretében csupán 2000 őszére fogadták el a Jegyzőkönyvet, így a kötelezettségvállalások időszaka valójában 2001. 01. 01-2003. 12. 31. között volt.

24 http://www.eeagrants.org/id/625.0 (2010. 07. 21.).

25 Financial Mechanism 1994-1998. Final Report. http://eeagrants.org/News/2009/Final-report-for-the-Financial-Mechanism-1994-1998 (2013. 07. 21.). 


\section{2. táblázat}

Az EGT mechanizmusok kiemelt területei (1994-2003, \%)

\begin{tabular}{|c|c|c|c|c|c|c|}
\hline \multirow{3}{*}{$\begin{array}{c}\text { Kiemelt } \\
\text { ágazatok }\end{array}$} & \multicolumn{4}{|c|}{ 1994-1998 } & \multirow{2}{*}{\multicolumn{2}{|c|}{$\frac{1999-2003}{\text { Elnyert támogatás }}$}} \\
\hline & \multicolumn{2}{|c|}{$\begin{array}{l}\text { Rendelkezésre álló } \\
\text { támogatás }\end{array}$} & \multicolumn{2}{|c|}{$\begin{array}{c}\text { Rendelkezésre álló } \\
\text { EBB-kölcsön }\end{array}$} & & \\
\hline & M EUR & $\%$ & M EUR & $\%$ & M EUR & $\%$ \\
\hline Környezet & 305 & 61 & 480 & 32 & 105,9 & 93,2 \\
\hline $\begin{array}{l}\text { Oktatás } \\
\text { és képzés }\end{array}$ & 110 & 22 & 45 & 3 & 6,2 & 5,4 \\
\hline Közlekedés & 85 & 17 & 975 & 65 & 1,5 & 1,3 \\
\hline Összesen & 500 & 100 & 1.500 & 100 & 113,6 & 100,0 \\
\hline
\end{tabular}

Forrás: saját szerkesztés ${ }^{26}$

A 2004. 05. 01.-2009. 04. 30. közötti támogatási periódus a korábbiakhoz képest jelentős eltéréseket mutat. Immáron két pénzügyi eszköz keretében került sor a támogatások allokációjára: az EGT-hez tartozó, mindhárom EFTA-állam által finanszírozott, multilaterális megállapodáson alapuló EGT Finanszírozási Mechanizmuson, valamint a kizárólag Norvégia által finanszírozott, kétoldalú nemzetközi megállapodáson alapuló Norvég Finanszírozási Mechanizmuson keresztül.

A kedvezményezett államok köre - tekintettel a korábbi és az újonnan csatlakozó államok közötti jelentős fejlettségbeli különbségekre - módosult. Az EGT Finanszírozási Mechanizmus keretében a régi uniós tagállamok (EU 12) közül Görögország, Portugália és Spanyolország támogatásra való jogosultsága és a rendelkezésre bocsátott összes támogatás mértéke is (!) megmaradt (azaz Îrország és Nagy-Britannia vonatkozásában Észak-Írország jogosultsága szűnt meg), míg az új, Norvég FM kizárólag az EU-hoz újonnan csatlakozó tíz új tagállam támogatását biztosította. A két FM által rendelkezése bocsátott összeg (1,239 milliárd euró) pedig a korábbi forrásallokáció csaknem tízszerese. A dotáló országok aspektusából érdekesség, hogy amellett, hogy a Norvég FM támogatásait kizárólag Norvégia finanszírozza, az EGT FM finanszírozását is $94,5 \%$-ban Norvégia biztosítja. A kedvezményezett államok aspektusából vizsgálva a két pénzalap támogatásait pedig megállapítható, hogy hazánk a második legtámogatottabb állam mindkét mechanizmus tekintetében.

Az EGT és a Norvég FM keretében nyújtott támogatások céljai jelentősen kiegészültek, illetve a meglévő preferenciák differenciálódtak. Új elemek jelentek meg, úgymint a bel- és igazságügyi együttmüködés, és nevesítésre kerültek a prioritások szintjén is a helyi önkormányzatok. Sajátos vonás a helyi önkormányzatok közszolgáltatás-szervezéséhez, igazgatásához kapcsolódó humánerőforrás-fejlesztési támogatás, hiszen látszólag most jelenik meg a helyi önkormányzatok támogatásának preferálása, azonban az eddigi támogatások jelentős része szintén szubnacionális szinten realizálódott. A regionális politika és a határon átnyúló együttmúködés támogatására pedig csupán a Norvég FM keretében volt lehetőség pályázni. A támogatott prioritások vizsgálata alapján megállapítható, hogy míg a finanszírozási mechaniz-

26 Financial Mechanism 1994-1998. Final Report, http://www.eeagrants.org/id/625.0 (2010. 07. 21.) alapján. 
mus(-ok) keretében nyújtott támogatások eleinte a Kohéziós Alap céljaihoz hasonultak, a 2004-2009-es időszakra leginkább az uniós alap támogatásainak komplementereiként azonosíthatók, még ha céljuk hasonló is, tudniillik a gazdasági és szociális kohézió erösítése. Ezt igazolja többek között az is, hogy az EGT és a Norvég FM által jelentősen támogatott kulturális örökségvédelem és az egészségvédelem támogatása nem a kohéziós politika keretében fogalmazódik meg elsődleges célként, az EU költségvetéséböl való részesedésük pedig elenyésző. Az adatok hazánkra vonatkozóan emellett más szempontból is figyelemre méltóak. Az EGT és a Norvég FM keretében hazánkban az átlagosnál magasabb az akadémiai kutatásnak és a humánerőforrás-fejlesztésnek a támogatottsága, az átlagoshoz képest viszont kevésbé priorizált terület a regionális politika és a határon átnyúló együttmüködés, a projektgenerálás és a projekt végrehajtása során a menedzsmenthez nyújtott szakmai támogatás. ${ }^{27}$

A 2004-2009 közötti időszak támogatásaira csak a 2004-ben az EU-hoz és az EGT-hez csatlakozó 10 új tagállam volt jogosult. Az Európai Unióhoz 2007. január 1-jén, az Európai Gazdasági Térséghez pedig 2007 júliusában ${ }^{28}$ csatlakozó Bulgária és Románia számára ezért 2007-2009 között az EGT Finanszírozási Mechanizmus keretében 72 millió eurót bocsátottak rendelkezésre, ${ }^{29}$ Norvégia pedig bilaterális megállapodások alapján (kvázi Norvég FM keretében) további 68 millió euró összegủ támogatást biztosított.

A 2009. 05. 01.-2014. 04. 30. közötti időszakra szóló megállapodások az előző időszakhoz képest az EGT FM esetében 31\%-os, a Norvég FM esetében pedig 22\%os növekedést eredményeztek. A két mechanizmus keretében nyújtott összes támogatás $97 \%$-át jelenleg is Norvégia biztosítja. ${ }^{30}$ Emellett az EGT Finanszírozási Mechanizmus 2009-2014-es támogatásairól szóló hivatalos tárgyalások során arról állapodtak meg, hogy a pénzügyi válság miatt Izland hozzájárulásai ne növekedjenek abszolút értékben. ${ }^{31} \mathrm{~A}$ kedvezményezett országok vonatkozásában pedig megállapítható, hogy Görögország, Portugália és Spanyolország ${ }^{32}$ 2009-2014 között az EGT FM alapján még továbbra is jogosult támogatásokra, a Norvég FM alapján azonban továbbra sem. A három állam által összesen elnyerhető támogatás mértéke pedig nőtt. Változás figyelhető meg Románia és Bulgária támogatottságában, ami relatív és abszolút értékben is jelentősen nőtt. Ez csak részben ered abból, hogy a két állam a 2004-2009-es időszak forrásaiból csupán 2007-től részesült támogatásban. A többi állam által felhasználható keretek nem mutatnak jelentős változást.

Horvátország 2013. július 1-jével csatlakozott az Európai Unióhoz, amellyel egyidejüleg fennáll a kötelezettsége az EGT-tagság iránti kérelem benyújtására. ${ }^{33}$ Noha Horvátország már 2012. szeptember 13-án benyújtotta csatlakozási kérelmét az Eu-

27 Rules and Procedures for the Implementation of the EEA Financial Mechanism 2004-2009.; Rules and Procedures for the Implementation of the Norwegian Financial Mechanism 2004-2009.

28 http://www.norwaygrants.org/en/About-the-programmes2/ (2013. 07. 20.).

29 Addendum to Protocol 38A, Article 2.

$30 \mathrm{http} / / /$ www.eeagrants.org/id/1457.0 (2010. 07. 19.).

$31 \operatorname{COM}(2010) 234,3$.

32 Spanyolország 2013. december 31-ig jogosult átmeneti támogatásra.

33 EEA Agreement, Article 128. Point 1. 
rópai Gazdasági Térséghez, a tárgyalások pedig 2013. március 15-én meg is kezdődtek, a csatlakozási szerződés megkötésére még nem került sor. A Bizottság továbbá javasolta a Tanács számára, hogy hatalmazza fel a tárgyalások megkezdésére a mechanizmusok kapcsán, ${ }^{34}$ viszont még a tanácsi határozat sem született meg.

A két mechanizmus keretében rendelkezésre bocsátott támogatások eloszlásának a változását a következő táblázat szemlélteti.

\section{3. táblázat}

Az EGT és a Norvég FM támogatásai a kedvezményezett államok szerinti bontásban (2004-2009, 2009-2014)

\begin{tabular}{|l|r|r|r|r|r|r|}
\hline \multirow{2}{*}{$\begin{array}{c}\text { Kedvezmé- } \\
\text { nyezett állam }\end{array}$} & \multicolumn{3}{|c|}{$\begin{array}{c}\text { Indikatív keretösszegek } \\
\text { 2004-2009 (M EUR) }\end{array}$} & \multicolumn{3}{c|}{$\begin{array}{c}\text { Indikatív keretösszegek } \\
\text { 2009-2014 (M EUR) }\end{array}$} \\
\cline { 2 - 7 } & EGT FM & Norvég FM & \multicolumn{1}{c|}{ Összesen } & \multicolumn{1}{c|}{ EGT FM } & \multicolumn{1}{c|}{ Norvég FM } & \multicolumn{1}{c|}{ Összesen } \\
\hline Lengyelország & 280,80 & 277,83 & 558,63 & 266,90 & 311,20 & 578,10 \\
\hline Magyarország & 60,78 & 74,28 & 135,06 & 70,1 & 83,20 & 153,30 \\
\hline $\begin{array}{l}\text { Cseh } \\
\text { Köztársaság }\end{array}$ & 48,54 & 62,37 & 110,91 & 61,4 & 70,40 & 131,8 \\
\hline Szlovákia & 32,34 & 37,99 & 70,33 & 38,35 & 42,40 & 80,75 \\
\hline Litvánia & 27,00 & 40,26 & 67,26 & 38,4 & 45,60 & 84,00 \\
\hline Lettország & 19,74 & 34,02 & 53,76 & 34,55 & 38,40 & 72,95 \\
\hline Románia & 50,50 & $48,00^{*}$ & 98,50 & 190,75 & 115,20 & 305,95 \\
\hline Spanyolország & 45,84 & - & 45,84 & 45,85 & & - \\
\hline Görögország & 34,26 & - & 34,26 & 63,40 & - & 45,85 \\
\hline Észtország & 10,08 & 22,68 & 32,76 & 23,00 & 25,60 & 48,40 \\
\hline Portugália & 31,32 & - & 31,32 & 57,95 & & -60 \\
\hline Bulgária & 21,5 & $20,00^{*}$ & 41,50 & 78,60 & 48,00 & 126,60 \\
\hline Szlovénia & 6,12 & 12,47 & 18,59 & 12,50 & 14,40 & 26,90 \\
\hline Ciprus & 1,26 & 3,40 & 4,66 & 3,85 & 4,00 & 7,85 \\
\hline Málta & 1,92 & 1,70 & 3,62 & 2,90 & 1,60 & 4,50 \\
\hline Összesen & 672,00 & $655,00^{*}$ & $1.307,00$ & 988,50 & 800,00 & $1.788,50$ \\
\hline
\end{tabular}

* Norvégia külön bilaterális megállapodások alapján (nem a Norvég Mechanizmusról szóló megállapodás kiegészítéseként) bocsátotta rendelkezésre Bulgária és Románia számára a támogatásokat.

Forrás: saját szerkesztés

A jelenlegi periódusban a két mechanizmus által legtámogatottabb területek a kutatás-fejlesztés, a környezetvédelem, valamint az energiahatékonyság, megújuló energia. Új eleme a Norvég FM megállapodásnak a tisztességes munkára és a háromoldalú párbeszédre való fókuszálás. A kiemelten támogatott területek, illetve a regionális politika és a határon átnyúló együttmüködés céljának az eltünése jól mutatja a két finanszírozási mechanizmusnak a kohéziós politikától való további távolodását.

34 COM(2012) 255 final (Brüsszel, 2012. 06. 01.) 


\section{4. táblázat}

Az EGT és a Norvég FM által támogatott területek (2009-2014)

\begin{tabular}{|l|c|l|r|}
\hline \multicolumn{1}{|c|}{$\begin{array}{c}\text { EGT FM támogatott területei } \\
\text { Magyarországon }\end{array}$} & $\begin{array}{c}\text { EGT FM- } \\
\text { hozzájárulás } \\
\text { (EUR) }\end{array}$ & Norvég FM támogatott területei & $\begin{array}{c}\text { Norvég FM- } \\
\text { hozzájárulás } \\
\text { (EUR) }\end{array}$ \\
\hline $\begin{array}{l}\text { Energiahatékonyság, megújuló } \\
\text { energia, alkalmazkodás az } \\
\text { éghajlatváltozáshoz }\end{array}$ & 23133000 & Kétoldalú kutatási együttmüködés & 24128000 \\
\hline Civil szervezetek támogatása & 12618000 & Zöld ipari innováció & 21216000 \\
\hline $\begin{array}{l}\text { Veszélyeztetett gyermekek és } \\
\text { fiatalok }\end{array}$ & 11216000 & $\begin{array}{l}\text { Népegészségügyi } \\
\text { kezdeményezések }\end{array}$ & 16640000 \\
\hline $\begin{array}{l}\text { Kulturális és természeti örökség } \\
\text { megörzése és megújítása }\end{array}$ & 11216000 & $\begin{array}{l}\text { Intézményfejlesztés és } \\
\text { együttmüködés a két fél } \\
\text { közintézményei, helyi és regionális } \\
\text { hatóságai között }\end{array}$ & 820000 \\
\hline $\begin{array}{l}\text { Ösztöndíjak } \\
\text { technikai segítségnyújtás, } \\
\text { kapcsolattartás) }\end{array}$ & 1752500 & $\begin{array}{l}\text { A méltányos munka és } \\
\text { háromoldalú párbeszéd } \\
\text { elömozdítása alap }\end{array}$ & 832000 \\
\hline $\begin{array}{l}\text { Nettó juttatás Magyarország } \\
\text { számára }\end{array}$ & $\begin{array}{l}\text { További juttatások (tartalék, } \\
\text { technikai segítségnyújtás, } \\
\text { kapcsolattartás) }\end{array}$ & $\begin{array}{l}\text { Nettó juttatás Magyarország } \\
\text { számára }\end{array}$ & 76960000 \\
\hline
\end{tabular}

Forrás: saját szerkesztés ${ }^{35}$

\section{A Svájci Hozzájárulás}

A Svájci Hozzájárulás elemzésére a két finanszírozási mechanizmusnál alkalmazott metódus alapján kerül sor.

\subsection{A Svájci Hozzájárulás szabályozásának keretei}

2006. február 27-én a Svájci Szövetségi Tanács az Európai Közösséggel aláirt, nem kötelező erejủ szándéknyilatkozatában kifejtette, hogy a kibővített EU gazdasági és társadalmi egyenlőtlenségeinek csökkentéséhez 1 milliárd svájci frankkal kíván hozzájárulni. 2006. március 24-én elfogadták a svájci szövetségi törvényt a keleteurópai államokkal és a Független Államok Közösségével való együttműködésről, melyet a svájci lakosok is támogattak a 2006. november 26-i népszavazáson. Miután a Svájci Hozzájárulás keretét a Svájci Szövetségi Parlament 2007-ben megszavazta, a 10 új uniós tagállammal bilaterális szerződések keretében keretmegállapodást ${ }^{36}$ írt alá. Míg az EGT és a Norvég Finanszírozási Mechanizmus esetében tehát már az

35 A 235/2011. (XI. 15.) kormányrendelet és a 236/2011. (XI. 15.) kormányrendelet B mellékletei alapján.

36 348/2007. (XII. 20.) kormányrendelet. 
EU és a donor államok közötti megállapodások (illetve azok jegyzőkönyvei) lefektetik az alapvető szabályokat, ${ }^{37}$ addig a Svájci Hozzájárulásnál Svájc és az adott kedvezményezett állam közötti keretmegállapodások és azok mellékletei határozzák meg részletesebben a végrehajtás alapvető szabályait. ${ }^{38}$

Magyarország részéről a tagállami szabályok elfogadása az alábbiak szerint alakult. A Svájci Hozzájárulás program területeiről és tárgyalási irányelveiröl szóló 2032/2007. (III. 7.) sz. kormányhatározat kijelölte a Nemzeti Fejlesztési Ügynökséget a Svájci Hozzájárulás program tekintetében a lebonyolítás koordinációjával kapcsolatos feladatok ellátására. A tárgyalások lezárultával 2007. december 20-án, Bernben került sor a keretmegállapodás aláírására Svájc és Magyarország között, mely a Svájci Hozzájárulás végrehajtási szabályait rögzítő 237/2008. (IX. 26.) sz. kormányrendelet (továbbiakban végrehajtási rendelet) által került kihirdetésre.

\subsection{A Svájci Hozzájárulás támogatásai}

Svájc már a rendszerváltástól támogatja a kelet-európai államok piacgazdaságba történő átmenetét. Svájc 1990-2006 között hozzávetőlegesen 3,45 milliárd svájci frank összegű támogatást nyújtott a kelet- és közép-európai átmeneti gazdaságoknak, és további 730000 svájci frank támogatás lett előirányozva 2007-2011 között ugyanezen, de még Unión kívüli államoknak. ${ }^{39}$ Svájc a 2004-ben EU-hoz csatlakozó európai államok gazdasági és társadalmi egyenlőtlenségeinek csökkentése céljából pedig felállította a Svájci Hozzájárulást, amely keretében 2007-2012 között a tíz új uniós államnak 1 milliárd svájci frank összegű, vissza nem térítendő támogatás odaítéléséről döntött. Emellett, elkülönítve, de hasonló céllal a 2007-ben uniós taggá váló Románia és Bulgária 257 millió svájci frank támogatásra jogosult a 2009-2014 közötti időszakban. ${ }^{40}$

\section{5. táblázat}

Svájc által nyújtott kohéziós támogatások (2007-2012, 2009-2014)

\begin{tabular}{|l|r|c|}
\hline \multicolumn{1}{|c|}{ Kedvezményezett állam } & $\begin{array}{c}\text { Rendelkezésre álló keret } \\
\text { 2007-2012 (CHF) }\end{array}$ & $\begin{array}{c}\text { Rendelkezésre álló keret } \\
\text { 2009-2014 (CHF) }\end{array}$ \\
\hline Lengyelország & 489020000 & \\
\hline Magyarország & 130738000 & \\
\hline Cseh Köztársaság & 109780000 & \\
\hline Litvánia & 70858000 & \\
\hline
\end{tabular}

37 A 2006. február 27-én a Svájci Szövetségi Tanács és az Európai Közösség között létrejött szándéknyilatkozatban nem fogalmazódik meg az uniós kohéziós politika figyelembevétele, a többéves keretről szóló megállapodások menete vagy az egyes prioritások minimális támogatottsági aránya.

38 A Svájci-Magyar Együttmüködési Program esetében maga a keretmegállapodás és annak három melléklete tartalmazza a Hozzájárulás stratégiai keretszabályozását, szabályzatát és eljárásrendjét, valamint a Program keretében működő alapok sajátos szabályait.

39 http://www.swissinfo.ch/eng/politics/Swiss_commitment_to_EU_could_face_new_test.html?cid=19680604 (2013. 05. 11.)

40 http://www.erweiterungsbeitrag.admin.ch/en/Home/The_Swiss_contribution (2013. 06. 05.) 


\begin{tabular}{|l|r|r|}
\hline \multicolumn{1}{|c|}{ Kedvezményezett állam } & $\begin{array}{c}\text { Rendelkezésre álló keret } \\
\text { 2007-2012 (CHF) }\end{array}$ & $\begin{array}{c}\text { Rendelkezésre álló keret } \\
\text { 2009-2014 (CHF) }\end{array}$ \\
\hline Szlovákia & 66866000 & \\
\hline Lettország & 59880000 & \\
\hline Észtország & 39920000 & \\
\hline Szlovénia & 21956000 & \\
\hline Ciprus & 5988000 & 181000000 \\
\hline Málta & 2994000 & 76000000 \\
\hline Románia & & 257000000 \\
\hline Bulgária & 1000000000 & \\
\hline Összesen & & \\
\hline
\end{tabular}

Forrás: saját szerkesztés

A Hozzájárulás forrásainak a felosztása a (Norvég FM keretében) Norvégia által használt allokációs kulcson alapul. (A számítás a kedvezményezett államok népességszámát és az egy före jutó jövedelmét veszi alapul. ${ }^{41}$ ) A Hozzájárulásból nyújtott támogatások rangsorában Lengyelország és Románia után hazánk jogosult a legnagyobb összeget lehívni.

A Svájci Hozzájárulásból az alábbi kiemelt támogatási területek kapcsán igényelhető támogatás: biztonság, stabilitás és reformok támogatása, környezet és infrastruktúra, magánszektor fejlesztése, valamint humánerőforrás- és társadalomfejlesztés. ${ }^{42}$ Míg az EGT és a Norvég FM a támogatások felosztási szabályainál a környezetvédelemmel, az éghajlatváltozással és a szén-dioxiddal kapcsolatos intézkedések preferálását; 30 , illetve $20 \%$-os minimális szintü támogatottságát köti ki elsődlegesen (emellett a civil társadalom 10\%-os minimális támogatottsága szerepel még), addig a Svájci-Magyar Együttmüködési Program (keretmegállapodás) a területi és a tematikus koncentráció elvét fekteti le. A területi koncentráció értelmében a Svájci-Magyar Együttmüködési Program legalább 40\%-át az észak-magyarországi és az észak-alföldi régiókra kell fordítani. Ezeken belül pedig a Borsod-Abaúj-Zemplén, Hajdú-Bihar, valamint Szabolcs-Szatmár-Bereg megye területein végrehajtásra kerülő programok és projektek kiemelten kezelendők. ${ }^{43} \mathrm{~A}$ tematikus koncentráció értelmében pedig a Hozzájárulás legalább $70 \%$-át a keretmegállapodás 1. mellékletében meghatározott prioritási területekre kell fordítani. ${ }^{44}$ A 2009-es módosítás következtében jelenleg 9 prioritási terület van hazánkban. A hazai prioritási területek meghatározása és a rendelkezésre bocsátott keretek szemléltetését a következő táblázat a 2010-es módosításokra figyelemmel szemlélteti. ${ }^{45}$

41 http://www.contribution-enlargement.admin.ch/en/Home/The_Swiss_contribution (2013. 07. 13.)

42 Memorandum of understanding between the President of the Council of the European Union and the Swiss Federal Council of 27 February 2006. 4. pont.

43 348/2007. (XII. 20.) kormányrendelet, 1. melléklet 4.

44 A Svájci-Magyar Együttműködési Program keretében rendelkezésre álló összeg 30\%-át a prioritásokon kívüli területekre is fordíthatta Magyarország, amelyekre hazánk végül 13,76\%-ot különített el.

45 A 2010-es módosítási javaslatot - az előzetes egyeztetések alapján és a keretmegállapodás 11. cikk (3) bekezdését jogalapként megjelölve - Svájc kezdeményezte levélváltás formájában, melyet miután maradéktalanul elfogadott a magyar fél (NFÜ elnöke), sor került a 66/2010. (III. 18.) kormányrendelet elfoga- 


\section{6. táblázat}

A Svájci Hozzájárulás magyar indikatív keretösszegei (M CHF)

\begin{tabular}{|c|c|c|c|c|c|}
\hline Prioritási területek & $\begin{array}{c}\text { Eredeti } \\
\text { indikatív } \\
\text { pénzügyi } \\
\text { keretösszeg } \\
\text { (2007, } \\
\text { M CHF) }\end{array}$ & $\begin{array}{c}\text { Módosított } \\
\text { indikatív } \\
\text { keretösszeg } \\
(2010 \\
\text { M CHF) }\end{array}$ & $\begin{array}{l}\text { Indikatív } \\
\text { keret- } \\
\text { összegek } \\
\text { aránya } \\
(2010, \%)\end{array}$ & $\begin{array}{c}\text { Elnyert } \\
\text { támogatás } \\
(2013, \\
\text { M CHF) }\end{array}$ & $\begin{array}{l}\text { Nyertes } \\
\text { pályá- } \\
\text { zatok } \\
\text { száma } \\
\text { (2013, } \\
\text { db) }\end{array}$ \\
\hline $\begin{array}{l}\text { 1. Biztonság, stabilitás, } \\
\text { reformok }\end{array}$ & 17,000 & 30,000 & 22,95 & 16,162 & 9 \\
\hline $\begin{array}{l}\text { - 1. prioritás: } \\
\text { Regionális fejlesztési } \\
\text { kezdeményezések } \\
\text { periferikus és hátrányos } \\
\text { helyzetú régiókban }\end{array}$ & 15,000 & 16,000 & 12,24 & 7,382 & 2 \\
\hline $\begin{array}{l}\text {-2. prioritás: Természeti } \\
\text { katasztrófák megelőzése } \\
\text { és kezelése }\end{array}$ & 2,000 & 2,000 & 1,53 & 6.780 & 6 \\
\hline $\begin{array}{l}\text {-9. prioritás: Biztonság és } \\
\text { biztonsággal kapcsolatos } \\
\text { jogszabályok }\end{array}$ & - & 12,000 & 9,18 & 2,000 & 1 \\
\hline $\begin{array}{l}\text { 2. Környezet és } \\
\text { infrastruktúra }\end{array}$ & 35,000 & 40,738 & 31,16 & 53,905 & 14 \\
\hline $\begin{array}{l}\text { - 3. prioritás: } \\
\text { Alapinfrastruktúra } \\
\text { javítása, helyreállítása, } \\
\text { modernizációja, környezet } \\
\text { fejlesztése }\end{array}$ & 30,000 & 35,738 & 27,34 & 34,906 & 6 \\
\hline $\begin{array}{l}\text {-4. prioritás: Határon } \\
\text { átnyúló környezeti } \\
\text { kezdeményezések, } \\
\text { biodiverzitás és } \\
\text { természetvédelem }\end{array}$ & 5,000 & 5,000 & 3,82 & 18,999 & 8 \\
\hline $\begin{array}{l}\text { 3. Magánszektor } \\
\text { támogatása }\end{array}$ & 17,500 & 17,500 & 13,39 & 17,365 & 3 \\
\hline $\begin{array}{l}\text { - 5. prioritás: Üzleti } \\
\text { környezet fejlesztése és } \\
\text { a finanszírozáshoz való } \\
\text { hozzáférés elősegítése a } \\
\text { kkv-k vonatkozásában }\end{array}$ & 14,500 & 14,500 & 11,10 & 15,216 & 1 \\
\hline $\begin{array}{l}\text {-6. prioritás: } \\
\text { Magánszektor fejlesztése, } \\
\text { kkv-k exportjának } \\
\text { elősegítése }\end{array}$ & 3,000 & 3,000 & 2,29 & 2,149 & 2 \\
\hline
\end{tabular}

dására. Ezen kormányrendelet 2. és 3. §-ainak hatálybalépéséről pedig a 18/2010 (IV. 9.) KüM-határozat rendelkezett. A Svájci Hozzájárulás magyar indikatív keretösszegeit így a Keretmegállapodás 1. melléklete és a 66/2010. (III. 18.) kormányrendelet alapján határoztam meg. A 2013. évi adatok pedig a Hozzájárulás kapcsán müködtetett adatbázis adatai: http://www.erweiterungsbeitrag.admin.ch/en/Home/Projects (2013. 08. 01.). 


\begin{tabular}{|c|c|c|c|c|c|}
\hline Prioritási területek & $\begin{array}{c}\text { Eredeti } \\
\text { indikatív } \\
\text { pénzügyi } \\
\text { keretösszeg } \\
(2007, \\
\text { M CHF) }\end{array}$ & $\begin{array}{c}\text { Módosított } \\
\text { indikatív } \\
\text { keretösszeg } \\
\text { (2010, } \\
\text { M CHF) }\end{array}$ & $\begin{array}{l}\text { Indikatív } \\
\text { keret- } \\
\text { összzegek } \\
\text { aránya } \\
(2010, \%)\end{array}$ & $\begin{array}{c}\text { Elnyert } \\
\text { támogatás } \\
(2013, \\
\text { M CHF) }\end{array}$ & $\begin{array}{l}\text { Nyertes } \\
\text { pályá- } \\
\text { zatok } \\
\text { száma } \\
\text { (2013, } \\
\text { db) }\end{array}$ \\
\hline $\begin{array}{l}\text { 4. Humánerőforrás- és } \\
\text { társadalomfejlesztés }\end{array}$ & 21,500 & 24,500 & 18,74 & 24,614 & 9 \\
\hline $\begin{array}{l}\text { - 7. prioritás: Kutatás és } \\
\text { fejlesztés }\end{array}$ & 8,500 & 11,500 & 8,80 & 11,614 & 8 \\
\hline - 8. prioritás: Egészségügy & 13,000 & 13,000 & 9,94 & 13,000 & 1 \\
\hline 5. További allokáció & 16,000 & 18,000 & 13,76 & $18,693^{*}$ & $4^{*}$ \\
\hline $\begin{array}{l}\text { - Pályázati Alap civil } \\
\text { szervezetek számára }\end{array}$ & 5,000 & 5,000 & 3,82 & 5,000 & 1 \\
\hline - Twinning és partnerség & 1,000 & 3,000 & 2,29 & 4,000 & 1 \\
\hline - Projekt Előkészítési Alap & 1,500 & 1,500 & 1,15 & 0,893 & 1 \\
\hline $\begin{array}{l}\text { - Menedzsmentköltség } \\
\text { - Svájc }\end{array}$ & 6,540 & 6,540 & 5,00 & 6,540 & $--^{*}$ \\
\hline $\begin{array}{l}\text { - Technikai segítség- } \\
\text { nyújtás költsége - } \\
\text { Magyarország }\end{array}$ & 1,960 & 1,960 & 1,50 & 2,260 & 1 \\
\hline 6. Nem allokált & 23,738 & - & - & - & - \\
\hline Összesen & 130,738 & 130,738 & 100,00 & 130,738 & 39 \\
\hline
\end{tabular}

* A svájci hatóságok által felhasználható források nem pályázati alapon elosztott források, a svájci fél oldalán jelentkező projektmenedzsment költségeket fedezik.

Forrás: saját szerkesztés

A táblázat alapján látható, hogy az elöirányzott összegek és az elnyert pályázatok megoszlása egyes prioritásoknál változott (pl. az 1. és a 9. prioritások összege jelentősen csökkent, a 4. prioritásé nött), a legpreferáltabb prioritások az alapinfrastruktúra javítása, fejlesztése, a határon átnyúló környezeti kezdeményezések, valamint a válság hatására növekvő igényként a kis- és középvállalkozások finanszírozáshoz való hozzáférésének az elősegítése. A környezetvédelemhez és a közlekedéshez kapcsolódó infrastrukturális beruházásokat támogató Kohéziós Alap céljaival ezek csak részben mutatnak átfedéseket. A tematikus és a földrajzi összpontosítás elvének érvényesülése mellett jellemző a forráselosztás koncentráltsága is, amit jól mutat a nyertes pályázatok száma, illetve a végrehajtási rendeletben szabályozott minimum összeg az igényelhető támogatások kapcsán. Megállapítható, hogy a Svájci Hozzájárulás, még ha a partnerség elvének alkalmazásával elő is segíti az egyes szektorok és ágazatok közötti kapcsolatok erősítését, elsődlegesen a közszektor intézményeinek nyújt támogatást. ${ }^{46}$

Napjainkban az ózdi közkutak elzárása illetve az azokból történő vízvétel korlátozása nemzetközi felháborodást keltett, és felvetődött a Svájci Hozzájárulás érintett-

46 Ezt támasztja alá a 242/2006. (XII. 5.) kormányrendelet 7. § (2) bekezdése, valamint a 237/2008. (IX. 26.) kormányrendelet $6 . \S(2)$ bekezdése is. Utóbbi szerint a Svájci-Magyar Együttműködési Program keretében elsősorban közcélt szolgáló, alapvetően nem profit szerzésére irányuló tevékenység finanszírozható. 
sége. A Svájci Hozzájárulás 3. prioritásainak forrásaiból ugyanis az ózdi önkormányzat 7165500 svájci frank összegủ támogatást nyert el az ivóvízhálózat felújitására. ${ }^{47}$ Ezért kérdésként merülhetett fel, hogy vajon a nemzetközi támogatásból finanszírozott beruházásokhoz kapcsolódóan az önkormányzat által esetleg vállalt szolgáltatások korlátozására került-e sor. A Svájci Hozzájárulásból társfinanszírozott fejlesztés a vízvezetékek cseréjét, a hálózat kibővítését és a városi ivóvíztároló-kapacitás bővítését támogatja, a fogyasztók hálózatra csatlakozásának a költségeit tehát ebből nem fedezhetik. Másrészt a csaknem két éve (2010. augusztus 23-án) jóváhagyott program még csupán a kivitelezésre kiírt közbeszerzés elbírálási szakaszában van, ezek miatt az ügy kapcsán nem vitatható a svájci forrásokból megvalósított program szerződésszerü teljesítése.

További aktuális kérdések is kapcsolódnak a Svájci Hozzájáruláshoz. Egyrészt látnunk kell, hogy az Unióhoz 2004-ben csatlakozó országok számára biztosított támogatások kapcsán a 2008 júliusában kezdődő pályáztatás, kiválasztási szakasz 2012 tavaszáig tartott. Az, hogy még mindig jelennek meg a Svájci Hozzájárulás finanszírozásával pályázati kírások, annak a következménye, hogy a források egy részét pályázati alapok nyerték el, ${ }^{48}$ az alapok pedig egyfajta közvetítőként jogosultak a forrásokat elosztani a Hozzájárulás céljainak megfelelöen. Ilyen alap hazánkban például a Svájci Magyar Civil Alap is, amelynek célja, hogy a két kiemelt (észak-alföldi és észak-magyarországi) régióban támogatásaival a civil szervezetek szolgáltatási tevékenységét fejlessze. Noha a projektek megvalósítása, így a svájci források felhasználása 2017. június 14-ig elhúzódhat, ${ }^{49}$ azt is hangsúlyozni kell, hogy újabb támogatási ciklusról nem döntött Svájc. Még nem bizonyos tehát, hogy a jövőben támogatni kívánja-e Svájc a tíz tagállamot, köztük hazánkat.

Horvátország 2013. július 1-jei uniós csatlakozása pedig Horvátország támogatásának a kérdését veti fel. Miután 2012. december 20-án Svájc az EU intézményeivel egy Horvátországnak nyújtandó lehetséges támogatásokról egyeztetett, 2013. március 8-án a svájci Szövetségi Tanács szándékát fejezte ki egy 45 millió svájci frank összegủ hozzájárulás biztosításáról Horvátország számára, áprilisban pedig a külügyi bizottságok is támogatták a hozzájárulás nyújtását. Mindazonáltal a döntéshozatali eljárás júliusig még nem záródott le.

47 Az SH/3/13 számú projekt összköltsége 8,43 millió svájci frank, a megvalósítás ideje pedig 2011-2015. A pályázatról lásd az alábbi forrásokat: Nemzeti Fejlesztési Ügynökség: Svájci Hozzájárulás - A lehetőségek széles skálája. http://www.nfu.hu/dokumentumok2 (2013. 07. 28.);

http://www.erweiterungsbeitrag.admin.ch/en/Home/Projects/Focus_on_projects/Water_supply_in_Hungary (2013. 07. 28.).

48 A pályázati alapokra fordítható támogatások indikatív összegéröl lásd a 6. táblázatot. Az alapokhoz kapcsolódó szabályokat a Svájci-Magyar Együttmüködési Program végrehajtási rendjéről szóló, 237/2008. (IX. 26.) kormányrendelet rögzíti.

49 http://www.news.admin.ch/NSBSubscriber/message/attachments/31206.pdf (2013. 07. 12.). 


\section{Az EGT és a Norvég FM, a Svájci Hozzájárulás, valamint az uniós kohéziós támogatások viszonya}

Az EGT FM esetében multilaterális, a Norvég FM és a Svájci Hozzájárulás esetében bilaterális az együttmüködés, kormányközi jelleggel; az uniós kohéziós támogatások esetében pedig sajátos, szupranacionális jellegü együttműködésröl beszélhetünk. A kooperáció jellegéből adódó különbségek miatt eltérő az adott időszakra elkülönített támogatásokról szóló döntési folyamat. Érdekesség azonban, hogy bár a két finanszírozási mechanizmus és a Svájci Hozzájárulás esetében a támogatást nyújtó és a kedvezményezett államok a nemzetközi jog szuverén alanyai, az Unió is szerződő fél, a Bizottság a végrehajtási és ellenőrzési folyamatokban is részt vesz.

Közös elem a támogatások elsődleges célja: a gazdasági és szociális/társadalmi kohézió erősítése. ${ }^{50}$ Mindegyik pénzügyi eszköz redisztribúciót valósít meg a tekintetben, hogy a finanszírozási mechanizmusokhoz, a Svájci Hozzájáruláshoz, illetve a kohéziós politika fedezetéül szolgáló uniós költségvetéshez hozzájáruló államok által rendelkezésre bocsátott forrásokat államok közötti vagy feletti szinten megállapított sajátos céloknak alárendelten, nem a hozzájárulás arányában osztják újra (a két finanszírozási mechanizmus és a Svájci Hozzájárulás esetében a donor államok egyáltalán nem is részesülnek a támogatásokból).

Közös vonás, hogy a források több évre elöre meghatározottak, azonban a támogatási rendszerek időintervallumai nem teljesen fedik egymást. Az átláthatóság növelése és a hatékonyabb koordináció érdekében célszerủ lenne az uniós pénzügyi kerethez igazítani mindhárom instrumentum időintervallumát, de legalább a Svájci Hozzájárulás esetében a kettős felosztást megszüntetni. Utóbbira lehetőség nyílik azáltal, hogy a tíz uniós tagállam első, 2007-2012 közötti támogatási ciklusát egyelöre nem hosszabbította meg Svájc, így Bulgária és Románia 2009-2014 közötti támogatási időszakának a lejárta közös támogatási időszaknak biztosítana lehetőséget, immáron Horvátország támogatásával kiegészülve - a donor állam támogató szándékának a fennmaradása esetén.

Az EGT és a Norvég Finanszírozási Mechanizmus forrásainak felosztásánál a kiindulási pontot az úgynevezett kohéziós kulcs jelentette (bizonyos átmeneti kiigazításokkal). ${ }^{51} \mathrm{~A}$ finanszírozási mechanizmusok kedvezményezettjei ezáltal többnyire megegyeznek a Kohéziós Alap mindenkori kedvezményezett területeivel (melyek a fejlődésben legelmaradottabb uniós államok). Részleteiben azért a megállapítás a következő táblázat adataival árnyalható.

50 A kohéziós politika céljait az EUMSZ XVIII. címe a Lisszaboni Szerződés óta a területi kohézióval is kiegészíti.

$51 \operatorname{COM}(2010) 234,3$. 


\section{7. táblázat}

Az Európai Unió Kohéziós Alapjából, valamint az EFTA-államok pénzügyi eszközeiböl támogatásra jogosult államok (2000-2013)

\begin{tabular}{|c|c|c|c|c|c|}
\hline Év & $\begin{array}{c}\text { Kohéziós Alap } \\
\text { kedvezménye- } \\
\text { zettjei }\end{array}$ & \multicolumn{2}{|c|}{$\begin{array}{c}\text { EGT-államok pénzügyi eszközeinek } \\
\text { kedvezményezettjei }\end{array}$} & \multicolumn{2}{|c|}{ Svájci Hozzájárulás } \\
\hline 2000 & \multirow{4}{*}{$\begin{array}{l}\text { - } 4 \text { régi } \\
\text { kohéziós állam } \\
\text { (Írország, } \\
\text { Görögország, } \\
\text { Portugália, } \\
\text { Spanyol-ország) }\end{array}$} & \multirow{4}{*}{\multicolumn{2}{|c|}{$\begin{array}{l}\text { Finanszírozási Eszköz } \\
\text { (1999-2003) } \\
\text { Írország, Észak-Írország (UK), } \\
\text { Görögország, Portugália, Spanyolország }\end{array}$}} & & \\
\hline 2001 & & & & & \\
\hline 2002 & & & & & \\
\hline 2003 & & & & & \\
\hline 2004 & \multirow{3}{*}{$\begin{array}{l}-4 \text { régi } \\
\text { kohéziós állam } \\
-(2004.05 . \\
01 \text {-töl) } \\
10 \text { új uniós } \\
\text { tagállam }\end{array}$} & \multirow{6}{*}{$\begin{array}{l}\quad \text { EGT FM } \\
\text { (2004. 05. 01.- } \\
\text { 2009. 04. 30.) } \\
\text { - Görögország, } \\
\text { Portugália, } \\
\text { Spanyolország } \\
\text { - } 10 \text { új uniós tagállam } \\
\text { - 2007-től Románia, } \\
\text { Bulgária }\end{array}$} & \multirow{6}{*}{$\begin{array}{l}\quad \text { Norvég FM } \\
\text { (2004. 05. 01.-- } \\
\text { 2009. 04. 30.) } \\
\text { - } 10 \text { új uniós tag- } \\
\text { állam } \\
\text { - } 2007-\text { től } \\
\text { Románia, } \\
\text { Bulgária }\end{array}$} & & \\
\hline 2005 & & & & & \\
\hline 2006 & & & & & \\
\hline 2007 & \multirow{7}{*}{$\begin{array}{l}-4 \text { régi } \\
\text { kohéziós } \\
\text { állam közül } \\
\text { Spanyolország } \\
\text { átmeneti } \\
\text { támogatása } \\
-12 \text { új uniós } \\
\text { tagállam }\end{array}$} & & & \multirow{6}{*}{$\begin{array}{l}2007- \\
2012 \\
-10 \text { új } \\
\text { uniós tag- } \\
\text { állam }\end{array}$} & \\
\hline 2008 & & & & & \\
\hline 2009 & & & & & \multirow{5}{*}{$\begin{array}{l}2009- \\
2014 \\
\text { Románia, } \\
\text { Bulgária }\end{array}$} \\
\hline 2010 & & \multirow{4}{*}{\begin{tabular}{l}
\multicolumn{1}{c}{ EGT FM } \\
(2009. 05. 01.- \\
2014. 04. 30.) \\
- Görögország, \\
Portugália \\
- Spanyolország \\
átmeneti támogatása \\
2013. 12. 31-ig \\
- 12 új uniós tagállam
\end{tabular}} & \multirow{4}{*}{$\begin{array}{l}\quad \text { Norvég FM } \\
\text { (2009. 05. 01.- } \\
\text { 2014. 04. 30.) } \\
\text { - } 12 \text { új uniós } \\
\text { tagállam }\end{array}$} & & \\
\hline 2011 & & & & & \\
\hline 2012 & & & & & \\
\hline 2013 & & & & & \\
\hline
\end{tabular}

Forrás: saját szerkesztés

A fenti táblázat alapján jól látható, hogy a támogatási időszakok különbözősége mellett maguk a támogatott államok is különbözhetnek a három pénzügyi eszköz kapcsán. Megállapítható, hogy míg az Unióba újonnan belépő államok a csatlakozásuktól ${ }^{52}$ kezdve jogosultak voltak támogatásokra, addig a csatlakozás előtti EU 15 átlag GNI-jának 90\%-a alatti nemzeti jövedelemmel rendelkező 4 tagállam (Írország, Görögország, Portugália és Spanyolország) a Norvég FM és a Svájci Hozzájárulás támogatásaira nem jogosult, az EGT FM csak Îrországot nem támogatja, a Kohéziós Alap pedig 2007-től a négy régi kohéziós állam közül csupán Spanyolország számára nyújt átmeneti támogatást. Az uniós regionális politika vonatkozásában (hiszen ebben benne vannak a strukturális alapok is) azonban az előző megállapítás már

52 A 2000-2006 közötti uniós költségvetési időszakban a tíz kelet-közép-európai tagállam a 2004-es csatlakozásig a Kohéziós Alap céljaival azonos prioritásokat támogató ISPA előcsatlakozási alap forrásaira volt jogosult - a többi előcsatlakozási alap (PHARE, SAPARD) támogatásai mellett. 
kiegészítendő. Bár 2007-2013 között a kohéziós politika keretében elsődlegesen (forrásainak $81,5 \%$-áig) támogatott területek valóban a fejlődésben legelmaradottabb régiók, illetve a Kohéziós Alap esetében a tagállamok, addig a kohéziós politika 2. célkitüzése keretében a legkevésbé fejlett régiókon kívüli régiók jogosultak támogatásra (a kohéziós politika forrásainak kb. 16\%-áig), a 3. célkitüzés viszonylag csekély összegeinek elosztása során pedig nem veszik figyelembe a fejlettségbeli mutatókat. ${ }^{53}$ Az Európai Unió által nyújtott regionális támogatásokból tehát a fejlettebb tagállamok, illetve a legfejlettebb régiók, megyék is jogosultak támogatásra. A Svájci-Magyar Együttmüködési Program e tekintetben kiemelendő, hiszen csak a kohéziós országok számára nyújtott támogatásoknak a földrajzi koncentráció elvének is meg kell felelniük, így a fejletlenebb uniós tagállamok legelmaradottabb régiói lesznek a támogatások $40 \%$-ának a kizárólagos jogosultjai.

A kedvezményezettek köre a vizsgált támogatások esetében más aspektusból is jól lehatárolható. Míg a Svájci Hozzájárulás keretében jogszabályi rendelkezés alapján elsősorban közcélt szolgáló, alapvetően nem profit szerzésére irányuló tevékenység finanszírozható, ${ }^{54}$ addig a két finanszírozási mechanizmus kapcsán csak a korábbi végrehajtási rendelet fogalmazta meg ezt a kötelezettséget ${ }^{55}$ jelenleg csak a nyertes pályázatok adatai alapján mondhatjuk el, hogy a gyakorlatban továbbra is jelentős részt a közszektor intézményei a kedvezményezettek. Az eddigiekkel ellentétben az uniós kohéziós támogatásoknak nem kiemelt kedvezményezettjei a közszektor különböző kormányzati szinten megjelenő intézményei. Közös vonás azonban, hogy a támogatások felhasználása kihat a szubnacionális kormányzati szintek müködésére, fejlesztéseire is. Amellett ugyanis, hogy a közszektor területi és települési szintü szereplői is jogosultak lehetnek uniós támogatásokra, a helyi vállalkozások és a civil szektor által megvalósított projektek kedvezőbb infrastrukturális környezetet teremtenek, a nem kormányzati szereplök munkahelyteremtő, foglalkoztatást bővítő projektjeinek és helyi innovatív ötleteinek az uniós támogatása szintén kihathat a helyi szolgáltatások nyújtására, fejlesztésére stb.

A decentralizáció kérdése a finanszírozási mechanizmusok és a Svájci Hozzájárulás tekintetében több aspektusból is vizsgálható, hiszen a támogatásokról való döntés, valamint a végrehajtás és az ellenörzés jogosítványai a donor és a kedvezményezett állam, valamint a kedvezményezett állam központi és szubnacionális kormányzati szintjei között egyaránt megosztható. A Svájci Hozzájárulás esetében a döntések egészen egyedi projekt szintig centralizáltak, ugyanis a donor állam hatóságai hozzák meg fő szabály szerint az egyedi projektet támogató döntést is (kivételként szolgálhatnak a támogatásközvetítő szervezetek által megvalósított finanszí-

53 A célkitűzésekről lásd a Tanács 1083/2006/EK rendeletét (2006. július 11.) az Európai Regionális Fejlesztési Alapra, az Európai Szociális Alapra és a Kohéziós Alapra vonatkozó általános rendelkezések megállapításáról és az 1260/1999/EK rendelet hatályon kívül helyezéséröl, 3. cikk. Az uniós regionális politika kedvezményezettjeire vonatkozóan lásd CsüRös Gabriella: Átalakuló támogatáspolitika a 2007-2013-as közösségi pénzügyi keret tükrében és ennek hatása az önkormányzatok forrásszerkezetére. In: HoRvÁtH M. Tamás (szerk.): Nézetek és látszatok. Decentralizáció a pénzügyi környezet szemszögéböl. KSzK ROP 3.1.1. Programigazgatóság, Budapest, 2007. 121-123.

54 237/2008. (IX. 26.) kormányrendelet, 6. § (2) bekezdés.

55 242/2006. (XII. 5.) kormányrendelet, 7. §. (2) bekezdés. 
rozási formák). Az EGT finanszírozási mechanizmusok esetében az előző támogatási időszakban (2004-2009) szintén a donor állam, illetve azok közös szervei döntöttek a pályázatokról, viszont az új támogatási időszak végrehajtási szabályait megállapító kormányrendelet ${ }^{56}$ értelmében az ún. programoperátorok döntenek a programok támogatásáról. ${ }^{57}$ Azáltal, hogy a két finanszírozási mechanizmus kapcsán bizonyos programokról a támogató döntést immáron tagállami szinten hozzák, döntéshozatali jogkörnek a donor és a tagállami szervek közötti megosztására került, a decentralizáció jegyében. A három EFTA kötődésű pénzügyi eszköz tekintetében a végrehajtás a donor állam és a kedvezményezett állam relációjában decentralizált, ugyanis a kedvezményezett államra hárul a végrehajtásért való felelősség. Végül hazánk mint kedvezményezett állam aspektusából a végrehajtás centralizált, mert a végrehajtás nem kerül megosztásra a központi és a szubnacionális szintek között, a tagállami kereteken belüli decentralizáció, regionalizáció nem valósul meg. Az uniós kohéziós politika keretében egyedi projektek támogatásáról fő szabály szerint a tagállamok irányító hatóságai döntenek, a nagyprojektekre vonatkozó döntés meghozatala azonban a jelenlegi (2007-2013 közötti) költségvetési időszakban is uniós szinten történik (a Bizottság által). Az uniós kohéziós politika keretében az Unió és az államok relációjában a megosztott végrehajtás jellemző, az adott tagállamon belül a szubnacionális szintek feladat- és hatáskörrel való felruházása pedig tagállami hatáskörbe tartozó döntés (tehát itt sem követelmény). Hazánkban a 2004-2006 és a 2007-2013 közötti időszakban sem kaptak érdemi, döntéshozatali jogkört a szubnacionális szintek szereplői.

A végrehajtás részletszabályait vizsgálva megállapítható, hogy mind az EGT és a Norvég FM, mind a Svájci Hozzájárulás esetében a rendelkezésre bocsátott keretek ugyanazon programozáson alapuló módszerrel kerülnek elköltésre, mint amelyet az EU strukturális alapjainál is használnak. ${ }^{58}$ Mindhárom EFTA pénzügyi eszköz hazai intézményrendszere speciális, de mechanizmusukban megjelennek az államháztartás hagyományos (például Magyar Államkincstár), illetve a kohéziós politika sajátos (pl. Nemzeti Fejlesztési Ügynökség, Európai Uniós Támogatásokat Auditáló Főigazgatóság) intézményi szereplői is, a támogatások kifizetési eljárásának lebonyolítása szükségszerüen és szintén az uniós metódushoz hasonlóan épül be a költségvetési szabályozásba. A három pénzügyi eszköz ellenőrzési rendszere egyrészt hasonul a hagyományos államháztartási ellenőrzés (az ún. államháztartási kontrollok) ${ }^{59}$ rend-

56 326/2012. (XI. 16.) kormányrendelet, 10. § 9. pont.

57 A programoperátor az együttmüködési megállapodás B mellékletében kijelölt, egy adott fejlesztési stratégia (programterület) tervezéséért és végrehajtásáért felelős szerv. A jelenlegi hazai szabályozás értelmében 3 programterület esetében a Nemzeti Fejlesztési Ügynökség irányító hatóságai, két programterület kapcsán szintén közszektorhoz kapcsolódó központi szervek (Nemzeti Környezetvédelmi és Energia Központ Nonprofit Kft., valamint a Tempus Közalapítvány) lettek kijelölve programoperátorként, két programterület vonatkozásában azonban a Finanszírozási Mechanizmus Iroda, azaz a donor államok szerve maradt a támogató döntést hozó szerv. Végül a további juttatásokról való döntés (pl. technikai segítségnyújtás és kétoldalú kapcsolatok nemzeti alapja) a nemzeti kapcsolattartó (NFÜ) feladat- és hatásköre lett.

$58 \operatorname{COM}(2010) 234,3$.

59 2011. évi CXCV. törvény 61-70. §. 
szeréhez, másrészt azonban az uniós támogatások ellenőrzési rendszerének többletelemei is megjelennek (pl. monitoring).

Közös, bár kivételt tűrő jellegzetességük, hogy a projektek utófinanszírozásúak, vissza nem térítendő támogatások által, melyek mellett valamilyen szintü önerő biztosítandó, tehát érvényesül a társfinanszírozás alapelve. A vissza nem térítendő támogatási forma alól kivételként szolgálhat például az EGT-EFTA-államok első finanszírozási mechanizmusa kapcsán az EBB-hitelek, a Svájci Hozzájárulás kapcsán a Pályázati Alap keretében müködtetett kockázati tökealapok, az uniós regionális politika kapcsán pedig például a Jeremie ${ }^{60}$ pénzügyi konstrukció.

A társfinanszírozás fogalmától megkülönböztetendő az addicionalitás elve. A társfinanszírozás egy széles fogalom, amely arra utal, hogy adott feladat, projekt megvalósítása több forrásból valósul meg, két vagy több finanszírozó egymás forrásait kiegészítve közremüködik. Az addicionalitás értelmében az adott támogatás egy meglévő tagállami költségvetési vagy önkormányzati szerepvállalást egészít ki, azaz a (többnyire fejlesztési) forrásokat nem helyettesítik, hanem azt kiegészítik. ${ }^{61}$ Addicionalitás esetén tehát az elvárás a közpénzekböl történő társfinanszírozás, és egy eredetileg is meglévő, azt a továbbiakban is biztosítandó finanszírozási szint. Az addicionalitás egyik EFTA pénzügyi eszköznél sem alapelv (bár a két finanszírozási mechanizmus esetében a korábbi támogatási ciklus Szabályzatok és Eljárásrend címü dokumentuma ${ }^{62}$ megfogalmazták a követelményét). A kohéziós támogatásoknál ennél sokkal markánsabban, alapelvként jelenik meg az addicionalitás, annak vizsgálata. ${ }^{63}$

Érdemes végül górcső alá venni az EFTA-tagállamok által biztosított három támogatási rendszer allokált összegeit. ${ }^{64}$

60 A Jeremie (Joint European Resources for Micro to Medium Enterprises) célja, hogy az Európai Beruházási Alap és Európai Regionális Fejlesztési Alap támogatásai által, pénzügyi közvetítőön keresztül hitelhez, kockázati tőkéhez, garanciához és szakmai tanácsadáshoz jussanak a mikro-, kis- és középvállalkozások.

61 MKI (IvÁN Gábor-Csürös Gabriella): Az Európai Unió fejlesztési forrásai. In: Bevezetés az Európai Unió támogatási rendszerébe. Tankönyv a köztisztviselők továbbképzéséhez. MKI, Budapest, 2007, 28.

62 Rules and Procedures for the Implementation of the EEA Financial Mechanism 2004-2009 13; Rules and Procedures for the Implementation of the Norwegian Financial Mechanism 2004-2009. 13. A jelenlegi, 2003. július 8-tól hatályos szabályzat (General Application Guide for the EEA and Norwegian Financial Mechanisms, 2009-2014) viszont nem tartalmazza az addicionalitás követelményét.

63 A Tanács 1083/2006/EK rendelete, 15. cikk, 9. cikk.

64 http://ec.europa.eu/regional_policy/policy/fonds/pdf/annexe-recto.pdf (2010. 08. 05.); 38B. Jegyzőkönyv; Megállapodás a Norvég Királyság és az Európai Unió között a Norvég Finanszírozási Mechanizmusról a 2009-2014 közötti idöszakban; http://www.contribution-enlargement.admin.ch/en/Home/The_Swiss_ contribution (2010. 08. 13.). 


\section{8. táblázat}

Az uniós, az EGT és a norvég, valamint a svájci kohéziós támogatások évi átlagos összege (M EUR)

\begin{tabular}{|c|c|c|c|c|c|}
\hline $\begin{array}{l}\text { Támogatási } \\
\text { rendszerek }\end{array}$ & $\begin{array}{c}\text { EU } 27 \\
\text { átlagos éves } \\
\text { támogatott- } \\
\text { sága }\end{array}$ & $\begin{array}{c}\text { EU } 12 \\
\text { átlagos éves } \\
\text { támogatott- } \\
\text { sága }\end{array}$ & $\begin{array}{c}\text { EU } 10 \\
\text { átlagos éves } \\
\text { támogatott- } \\
\text { sága }\end{array}$ & $\begin{array}{c}\text { Magyarország } \\
\text { átlagos éves } \\
\text { támogatott- } \\
\text { sága }\end{array}$ & Finanszírozó \\
\hline $\begin{array}{l}2007-2013 \\
\text { Összes uniós } \\
\text { kohéziós } \\
\text { támogatás } \\
\text { (1. célkitüzés } \\
\text { támogatásai) }\end{array}$ & $\begin{array}{r}49630,00 \\
(40323,14)\end{array}$ & $\begin{array}{r}25436,00 \\
(24569,86)\end{array}$ & $\begin{array}{r}21647,00 \\
(20871,71)\end{array}$ & $\begin{array}{r}3615,00 \\
(3270,00)\end{array}$ & EU \\
\hline $\begin{array}{l}\text { 2009-2014 } \\
\text { EGT, Norvég } \\
\text { Finanszírozási } \\
\text { Mechanizmus }\end{array}$ & 357,70 & 324,26 & 237,75 & 30,66 & $\begin{array}{r}\text { Izland, } \\
\text { Liechtenstein, } \\
\text { Norvégia }\end{array}$ \\
\hline $\begin{array}{l}\text { 2007-2012 } \\
\text { Svájci } \\
\text { Hozzájárulás } \\
\text { 2009-2014 } \\
\text { Románia, } \\
\text { Bulgária } \\
\text { támogatása }\end{array}$ & $193,38^{*}$ & $193,38^{*}$ & $153,85^{*}$ & $20,11^{*}$ & Svájc \\
\hline Összesen & $\begin{array}{r}50181,08 \\
(40874,22)\end{array}$ & $\begin{array}{r}25953,64 \\
(25087,50)\end{array}$ & $\begin{array}{r}22038,60 \\
(21263,31)\end{array}$ & $\begin{array}{r}3665,77 \\
(3320,77)\end{array}$ & $E U+E F T A$ \\
\hline
\end{tabular}

*Átváltási ráta: $1 \mathrm{EUR}=1,3 \mathrm{CHF}$

Forrás: saját szerkesztés

Az egy lakosra számított éves átlagos hozzájárulás adatai érdekes tanulságokat hordoznak magukban. Az Eurostat adatai alapján ${ }^{65}$ az uniós kohéziós politikához egy uniós állampolgár éves átlagban 99 euróval járul hozzá (az 1. célkitűzés, azaz a legelmaradottabb területek relációjában 80,5 euróval), míg ugyanúgy az uniós kohéziós célokhoz, de Svájc állampolgárai 25 euróval. Az egy lakosra jutó uniós kohéziós célokhoz való hozzájárulás, a három EGT-állam hozzájárulását (együttesen 357,7 millió euró) és lakosságszámát (együttesen 5211733 fő) vizsgálva, a három állam relációjában 68,6 euró/fő. ${ }^{66}$ Megjegyzendő, hogy mindegyik EFTA-állam kimagasló gazdasági teljesítőképességgel rendelkezik (még ha a válság hatására visszaesés is mutatkozott Izland gazdaságában). A négy EFTA-állam közül egyértelmüen Norvégia járul tehát hozzá lakosságszám-arányosan a legnagyobb összeggel az Európai Unió legfejletlenebb tagállamai felzárkózásához, Norvégia az EU kohéziójának legfőbb integráción kívüli pénzügyi támogatója.

65 Az EU 27 lakosságszáma 2010-es Eurostat adatok szerint 501064212 fö, Svájc lakossága pedig 7783026 fö.

66 Ennél jelentősebb a norvég lakosok tényleges hozzájárulása az uniós kohéziós célokhoz, hiszen mint láttuk, az EGT Finanszírozási Mechanizmust is jelentős részben (97\%-ban) Norvégia finanszírozza, a csaknem ugyanakkora támogatást nyújtó Norvég Finanszírozási Mechanizmust pedig kizárólag Norvégia. 
A fenti táblázat alapján más következtetéseket is megállapíthatunk. Az összes kohéziós politika által nyújtott támogatásnak csupán 51,25\%-a érhető el a 12 új uniós tagállam számára. Ennek csak részben lehet az oka az, hogy az uniós támogatások a fejlettségbeli mutatókat jelentős részben regionális szinten mérik, hiszen a fejlettebb uniós államokban is vannak periferikus, hátrányos helyzetü régiók. Ennek másrészt ugyanis lehet az is oka, hogy a tagállamok az uniós kohéziós politika cél- és eszközrendszerébe olyan elemeket is beépítettek (lásd pl. a 2. és 3. célkitüzés támogatásait), amelyek csökkentik az uniós költségvetés redisztribúciós jellegét. Ezt a markáns megállapítást árnyalhatja, hogy az összes uniós kohéziós támogatáshoz képest a kizárólag az 1. célkitüzés alá eső támogatások aránya 81,5\%.

Hazánk relációjában vizsgálva a fenti adatokat, megállapítható, hogy mind a két finanszírozási mechanizmus, mind a Svájci Hozzájárulás vonatkozásában hozzávetőlegesen a 12 új uniós tagállam támogatásának a 10\%-ában részesül Magyarország. Szembeötlő emellett a különbség az uniós és az EFTA-államok által nyújtott támogatások abszolút értékében. (A hazánk számára a két finanszírozási mechanizmus keretében rendelkezésre bocsátott éves átlagos támogatás az uniós támogatások 0,85\%-a, a Svájci Hozzájárulás keretében pedig az uniós támogatások 0,56\%-a.) Ez lehet az oka, hogy kevésbé kerültek az érdeklődés középpontjába az EFTA-államok által nyújtott támogatások.

\section{Zárógondolatok}

Az Európai Unió és az Európai Szabad Kereskedelmi Társulás mint két európai gazdasági integráció több mint fél évszázados múltra tekint vissza. A két integráció, illetve azok tagjai közötti együttmüködés viszont a kilencvenes évek rendszereket váltó érájában erősödött fel. Az akkor dinamikusan fejlődő Európai Unió vívmányaiból sajátos módon részesedni kívánó EFTA-országok ezzel egyidejűleg - illetve Svájc egyedi keretek között, viszonylag jelentős időbeli eltolódással - kohéziós célú pénzügyi eszközöket hoztak létre.

Az EGT és a Norvég Finanszírozási Mechanizmus, valamint a Svájci Hozzájárulás vizsgálata és az uniós kohéziós politikával való összehasonlítása alapján megállapítható, hogy sajátos kormányzati szintek közötti pénzügyi kapcsolatot eredményez a kohéziós támogatások rendszere. Azonban bármennyire is egyoldalú segélyező politikának tünnek a kohéziós célú támogatások, a kapcsolat- és érdekrendszer komplex, kölcsönös jogokkal (előnyökkel) és kötelezettségekkel (hozzájárulásokkal). Magának a vissza nem térítendő támogatások nyújtásának a létjogosultsága is ebből a kölcsönös viszonyból fakad.

Izland esete kiváló példája, hogy az EGT-n belül a két gazdasági integráció egyaránt előnyökkel és hátrányokkal jár, annak eldöntése pedig, hogy melyik közösségben való tagság éri meg, nehéz, országspecifikus, emellett változó kimenetelü lehet.

Az izlandi parlament által (szük többséggel) megszavazott uniós csatlakozási kérelmet 2009 júliusában nyújtotta be Izland, az Európai Tanács 2010. június 17-i ülésén 
pedig a csatlakozási tárgyalások megnyitásáról döntött. ${ }^{67}$ Noha a csatlakozási tárgyalások jól haladtak, ${ }^{68} 2013$. január 14-én Izland bejelentette a tárgyalások felfüggesztését a parlamenti választásokra hivatkozva, a választások után alakult új kormány pedig egy közeljövőben megtartandó népszavazás kimenetelétől tette függővé a tárgyalások folytatását (aminek negatív kimenetele esélyes, hiszen az euroszkeptikus pártokat többen támogatták a választásokon). A csatlakozás mellett szóló legföbb érv - az euróövezet védőhálója - egyre kevésbé meggyőző Izland számára, hiszen a válság által erősen sújtott ország immáron az uniós átlagnál kedvezőbb gazdasági növekedési mutatókkal bír. ${ }^{69} \mathrm{~A}$ szigetország sajátos gazdasága számára (amely jelentősen épít a természeti erőforrásokra, különösen a halászatra és geotermikus energiára) szintén kedvezőtlen lenne az uniós tagság. Bár az EGT keretében az Unión kívüli tagállamok, anélkül hogy részt vennének az uniós jogalkotásban, kötelesek a belső piacra vonatkozó uniós acquis átvételére, ez a kötelezettség azonban néhány uniós politika vonatkozásában, így például az Izland számára különösen fontos mezőgazdasági, halászati politika területén nem áll fenn. A 2010 júliusától tagjelölti státuszban lévő Izland tehát beírta magát az EU „táncrendjébe”, azonban mostanság inkább kifelé táncol a kérők sorából, és ismét kedvezőbbnek ítéli az EGT-n belül az EFTA-tagságot. Izland esete nemcsak a külső és belső tényezők által meghatározott egyedi tagállami érdekek lehetséges módosulásait, hanem a szorosabb együttműködés, az uniós tagság változó vonzerejét és az európai gazdasági integrációk közötti kapcsolatokat is jól illusztrálja.

A gazdasági integrációk dimenziójában kialakult kapcsolatrendszer alapvető sajátossága, hogy míg a támogatások számszerüsíthetők és számszerüsítettek, addig az európai integrációkból származó további közvetlen és közvetett elönyök nehezebben kimutathatók.

\section{Abstract}

The economic cooperation between the EU and EFTA states constitutes a special cooperation form in several ways: the actors of cooperation (economic integrations and their Member States), the legal and institutional framework and the budgetary relations also have unique features. In our study the rules and changes of the EEA and Norwegian Financial Mechanism, as well as the Swiss Contribution are analyzed from aspect of integration theories and financial law. In the framework of historical analysis and comparative method the financial instruments of EFTA states are compared with the EU Cohesion and Structural Funds with the help of evaluating statistical data.

67 Az Európai Tanács (2010. június 17.) következtetései, Brüsszel, 2010. június 17. 24. pont.

68 A tárgyalási fejezetek kétharmadát már megnyitották, kb. egyharmadát már le is zárták, bár a legvitatottabb területek (halászat, közös agrárpolitika, energiapolitika) még érintetlenek maradtak.

69 Blockmans, Steven: Too cold to handle: EU accession talks with Iceland. Centre for European Policy Studies. 3 June 2013, 2. 